Columbia Law School

Scholarship Archive

2018

\title{
Another One BITes the Dust: The Distance between Luxembourg and the World is Growing after Achmea
}

Petros C. Mavroidis

Columbia Law School, petros.mavroidis@unine.ch

Carlo M. Cantore

University of Antwerp

Follow this and additional works at: https://scholarship.law.columbia.edu/faculty_scholarship

Part of the European Law Commons, and the International Trade Law Commons

\section{Recommended Citation}

Petros C. Mavroidis \& Carlo M. Cantore, Another One BITes the Dust: The Distance between Luxembourg and the World is Growing after Achmea, EUROPEAN UNIVERSITY INSTITUTE, ROBERT SCHUMAN CENTRE FOR Advanced Studies, Global Governance Programme Working Paper No. RSCAS 2018/47 (2018).

Available at: https://scholarship.law.columbia.edu/faculty_scholarship/2286

This Working Paper is brought to you for free and open access by the Faculty Publications at Scholarship Archive. It has been accepted for inclusion in Faculty Scholarship by an authorized administrator of Scholarship Archive. For more information, please contact scholarshiparchive@law.columbia.edu. 

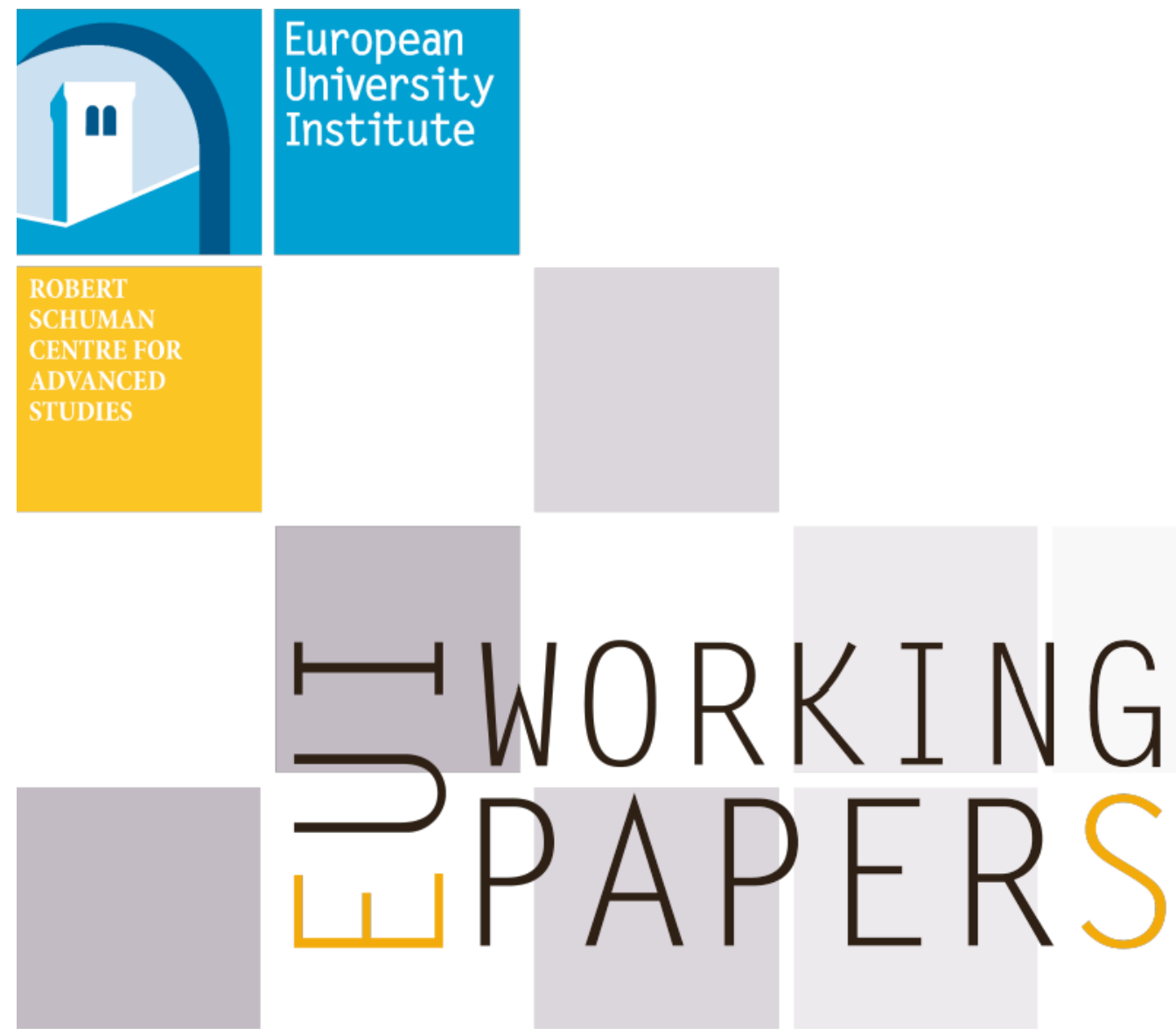

RSCAS 2018/47

Robert Schuman Centre for Advanced Studies Global Governance Programme-315

Another One BITes the Dust

The Distance between Luxembourg and the World is Growing after Achmea

Carlo M. Cantore and Petros C. Mavroidis 
European University Institute

Robert Schuman Centre for Advanced Studies

Global Governance Programme

Another One BITes the Dust

The Distance between Luxembourg and the World is Growing after Achmea

Carlo M. Cantore and Petros C. Mavroidis

EUI Working Paper RSCAS 2018/47 
This text may be downloaded only for personal research purposes. Additional reproduction for other purposes, whether in hard copies or electronically, requires the consent of the author(s), editor(s). If cited or quoted, reference should be made to the full name of the author(s), editor(s), the title, the working paper, or other series, the year and the publisher.

ISSN 1028-3625

(C) Carlo M. Cantore and Petros C. Mavroidis, 2018

Printed in Italy, September 2018

European University Institute

Badia Fiesolana

I - 50014 San Domenico di Fiesole (FI)

Italy

www.eui.eu/RSCAS/Publications/

www.eui.eu

cadmus.eui.eu 


\section{Robert Schuman Centre for Advanced Studies}

The Robert Schuman Centre for Advanced Studies, created in 1992 and currently directed by Professor Brigid Laffan, aims to develop inter-disciplinary and comparative research on the major issues facing the process of European integration, European societies and Europe's place in 21st century global politics.

The Centre is home to a large post-doctoral programme and hosts major research programmes, projects and data sets, in addition to a range of working groups and ad hoc initiatives. The research agenda is organised around a set of core themes and is continuously evolving, reflecting the changing agenda of European integration, the expanding membership of the European Union, developments in Europe's neighbourhood and the wider world.

For more information: http://eui.eu/rscas

\section{The Global Governance Programme}

The Global Governance Programme is one of the flagship programmes of the Robert Schuman Centre. It is a community of outstanding professors and scholars, that produces high quality research and engages with the world of practice through policy dialogue. Established and early-career scholars work on issues of global governance within and beyond academia, focusing on four broad and interdisciplinary areas: Global Economics, Europe in the World, Cultural Pluralism and Global Citizenship.

The Programme also aims to contribute to the fostering of present and future generations of policy and decision makers through its executive training programme: the Academy of Global Governance, where theory and 'real world' experience meet and where leading academics, top-level officials, heads of international organisations and senior executives discuss on topical issues relating to global governance.

For more information: http://globalgovernanceprogramme.eui.eu

The European University Institute and the Robert Schuman Centre are not responsible for the opinions expressed by the author(s). 


\begin{abstract}
The CJEU has become a gatekeeper. Ever since Opinion 1/91, the CJEU has been imposing barriers to the recognition of decisions by foreign jurisdictions. Its recent Achmea decision is the natural consequence of case law so far. This attitude would not be problematic by itself since, through this attitude, the European Union would still be liable at the international plane, even if it did not implement its international obligations (liability- over property rules). This is not the end of the story. The CJEU accepts the, in principle, relevance of decisions by some international jurisdictions. However, the CJEU has repeatedly failed to establish clear criteria to identify ex ante the circumstances under which this will be the case. As things stand, recognition of foreign judgments is more of a line in the sand, than a dictum set in stone. This attitude is hardly reconcilable with the quintessential elements of a Rechtsstaat.
\end{abstract}

\title{
Keywords
}

Achmea; CJEU; Intra-EU BITs; preliminary rulings. 


\section{EU Integration and Public International Law*}

The Court of Justice of the European Union (CJEU) has been quite busy in recent times dealing with cases where the legal significance of rulings by international courts has been at stake. In fact, more than that: the question has been raised whether individuals, companies, Member States, or even the European Union (EU) itself can, and, if so, under what conditions, submit to foreign jurisdictions.

The CJEU will have to address this question head on when it issues its Opinion 1/17. ${ }^{1} \mathrm{We}$ are still a few months away from that day. Following a request by Belgium, the consistency of the investment chapters in CETA (Canada-European Union Trade Agreement), which provide for the establishment of a court dealing with investor-state disputes, with EU law will be the plat de resistance for the judges in Kirchberg, Luxembourg.

Nevertheless, the recent Achmea $^{2}$ decision by the CJEU seems to all but prejudge the outcome in Opinion 1/17 as well. The Court prefers to dance to its own rhythm, and has shown to have little taste for international judgments. In stating that much, we have implicitly claimed that Achmea is no one-off incident. Our main claim thus, is that the CJEU has been moving into this direction for some time now. Maybe because of the relative infrequency of cases dealing with this issue, few noticed (and we belong to them) that Achmea-type decisions represent a conscious choice, a deep persuasion of the members of the CJEU that opening to foreign jurisdictions might eviscerate the homogeneity in the interpretation and application of EU law, since its quintessential elements risk being misunderstood by foreign judges and arbitrators.

This approach, though, is not without problems. There is uncertainty regarding the conditions under which the EU can embed courts in international agreements signed with third countries and submit its international disputes to them. The CJEU repeats ad nauseam almost that it is possible to do so, but has yet to explain when and how precisely. We will argue that the main reason why this is the case, has to do with the very expansive understanding of EU law that the CJEU has developed. It understands conferral in very loose terms.

And then, why would, under the circumstances, anyone contract in this way with the EU, knowing that courts that it might be co-establishing with the EU risk having no impact within the EU legal order? True, (lack of) implementation within the EU should not be confused with international responsibility that the EU incurs any time it contracts internationally even if it has not implemented what it has contracted. The EU seems to prefer liability- over property rules, but its preferences and those of its international partners might not match. One could, further, ask what is the implication of the CJEU as far as enforcement is concerned. And so on and so forth.

To substantiate our claim, we will first discuss Achmea, what it stands for, and where it came from (Section 2). We will then move to show the shortcomings of the approach, namely, the uncertainty it creates (Section 3). We will refrain from detailing the consequences of uncertainty. We have already highlighted above, that it might negatively affect the incentive of foreign players to transact with the EU and its member states, and it might also increase transaction costs (assuming a decision to transact is privileged anyway). These are questions that require individual, detailed treatment. In Section 4, we recap our main conclusions.

\footnotetext{
We would like to thank Jonathan Chevry, James Devaney, Claus-Dieter Ehlermann, Ian Forrester, David Kleimann, Francesco Pili, William Valasidis, Nils Wahl, and Jan Wouters for numerous discussions on this topic. Remaining errors are of course our own. The views expressed in this article are the authors' only and should not be attributed to the WTO or its Members.

1 Request for an opinion submitted by the Kingdom of Belgium pursuant to Article 218(11) TFEU (Opinion 1/17)

2 CJEU, Case C-248/16, Slowakische Republik (Slovak Republic) v. Achmea BV [2018], ECLI:EU:C:2018:158.
} 


\section{The Achmea Decision}

On 6 March 2018, The CJEU rendered its preliminary ruling in a case brought by the Slovak Republic against Achmea BV (Achmea) before German courts. The importance of this case cannot be overstated as it is the first time that the CJEU issued a judgement on the compatibility of intra-EU bilateral investment treaties (BITs) with EU law. ${ }^{3}$

\subsection{Facts}

The case originates in an award rendered in December 2012 by an arbitration tribunal established under the BIT between the Slovak Republic and the Kingdom of the Netherlands. The BIT was negotiated between Czechoslovakia and the Netherlands. It was concluded in 1991 and entered into force in 1992. The Slovak Republic succeeded to the rights and obligations of Czechoslovakia under the aforementioned BIT in 1993, after the so-called "velvet revolution", a few years before its accession to the EU (2004).

Achmea is a Dutch supplier of insurance services. When the Slovak Republic reformed its health system in 2004 and opened its private sickness insurance market, Achmea obtained the necessary authorizations to operate a subsidiary in that country. In 2006 and 2007, the Slovak Republic partially modified the pre-existing regime, and prohibited the redistribution of profits generated by private providers in the health insurance market. Achmea challenged the legislative measures in arbitration proceedings against the government of the Slovak Republic. The arbitral tribunal chose Frankfurt as its seat, as per the applicable United Nations Commission on International Trade Law (UNCITRAL) rules. As a result, German law applied to the proceedings, including the possibility to submit the arbitral award to judicial review under a specific set of circumstances.

In December 2012, the arbitral tribunal found in favor of Achmea, and ordered the Slovak Republic to pay damages for over 22 million euros. The Government of the Slovak Republic brought an action to set aside the arbitral award before local courts in Germany. Whilst the Higher Regional Court in Frankfurt dismissed the action, the Federal Court of Justice, on appeal, filed a request for preliminary ruling before the CJEU. The referring court submitted questions concerning the compatibility of the arbitration clause contained in Article 8 of the Dutch-Slovak BIT with Articles 18, 267 and 344 of the Treaty on the Functioning of the European Union (TFEU). Put simply, the matter before the CJEU was whether a provision in an international agreement between two Member States, whereby an investor originating in one of these Member States has the right to bring proceedings against the host Member State before an ISDS arbitration tribunal (rather than a domestic court), is consistent with EU law.

The CJEU started its analysis recalling its settled case law whereby an international agreement cannot affect the allocation of powers as determined by the EU treaties and the "autonomy" of the EU legal system (para. 32) ${ }^{4}$. To preserve that autonomy, Article 344 of the TFEU prevents EU Member States from submitting any dispute involving the application or interpretation of the Treaties to methods of settlement that are not specifically envisaged by the Treaties themselves. The gist of the argument is the following. The treaties constitute the primary law of the EU legal order. They have primacy over the

It should be noted that this is not the only case where the EU institutions are confronting intra-EU BITs. Following an arbitration award in Micula v. Romania, the goverment of Romania was condemned to offer compensation to a Swedish investor because it had breached the "fair and equitable treatment" clause in the Sweden-Romania BIT. The Commission ordered Romania to avoid compensating the private investors, otherwise it would be violating the EU State Aid rules. The investor lodged a complaint against Romania for refusing to compensate, and the case is currently pending before the CJEU (Case T-694/15).

4 See, in particular: ECJ, Opinion 1/91, Draft agreement between the European Community and the countries of the European Free Trade Association relating to the creation of the European Economic Area [1991] ECLI:EU:C:1991:490; CJEU, Opinion 2/13, Accession of the European Union to the European Convention for the Protection of Human Rights and Fundamental Freedoms [2014] ECLI:EU:C:2014:2454. 
domestic law of the Member States, which are under the duty to cooperate to ensure that EU law is faithfully implemented. To prevent divergent interpretations of the same provisions of EU law by local courts of law, Article 267 of the TFEU allows the Member States' courts to submit requests for preliminary rulings to the CJEU concerning the interpretation of the Treaties or the validity of acts of the EU institutions. When such courts or tribunals are of last instance, they are obliged to do so.

In the view of the CJEU, whenever the interpretation or the application of EU law is relevant in the context of a dispute, the judge evaluating the matter can (or must, if it is a last instance judge) seek the views of the CJEU through a request for a preliminary ruling (paras. 37 - 39). Through this procedure, EU law will be interpreted in a harmonious/consistent manner, assuming of course that the CJEU observes this function. Students of EU law know that this has not always been the case. For starters, there is nothing like stare decisis in EU law. Nevertheless, the CJEU has de facto by and large respected its prior rulings. And all changes in jurisprudence stem from the same body, since the CJEU has the monopoly of interpreting EU law. It is this monopoly-position of the CJEU that best captures the idea of autonomy of the EU legal order, that is, that EU law will not be shaped through interpretative exercises by courts other than the CJEU.

According to settled case-law, for a judicial body to be a "court or tribunal" for the purposes of Article 267 TFEU, that is, for a "court or tribunal" to have the right to refer issues for preliminary ruling to the CJEU, the referring court must be based in a Member State. Furthermore, besides its nationality, it must be a "body established by law" that is "permanent", is vested with "compulsory jurisdiction", is "independent", applies "rules of law" and whose procedure is "inter partes". ${ }^{5}$ Clearly, a court not based in a Member State is under no obligation to refer to the CJEU a question for preliminary ruling. As a result, in case a "third" court were to discuss an issue involving interpretation of EU law, the autonomy of the EU legal order would be in peril, as there is no guarantee at all that the "third" court would observe prior CJEU jurisprudence dealing with the same issue.

Against this background, the CJEU examined the content of the BIT at the origin of the dispute. Article 8 thereof included an arbitration clause, whereby arbitral tribunals could be established to rule on cases concerning the alleged infringement of the BIT (paras. 45 and ff.). Article 8(6) of the BIT, in particular, provided that arbitrators must take into account the law in force of the parties as well as any other relevant agreements between them. On the one hand, thus, Article 8 specified that arbitrators would evaluate whether an infringement of the BIT had occurred. On the other hand, the contextual reference to agreements between the states concerned might imply that the arbitral tribunal could interpret or apply EU law to solve a matter before it. In fact, EU law qualified both as part of the domestic law of the Slovak Republic and the Netherlands as well as an agreement between the two states.

The CJEU found that the tribunal envisaged in the BIT was not part of the judicial system of the two Member States concerned and, therefore, could not be classified as a court or tribunal of a Member State for purposes of Article 267 TFEU (para. 49).

The CJEU distinguished between the arbitral tribunal in the Dutch-Slovak BIT and other mechanisms for the resolution of disputes that had survived its scrutiny. For instance, the Court had previously ruled that a tribunal common to two or more Member States such as the Benelux Court of Justice was not incompatible with the EU treaties (Case Parfums Christian Dior). Whilst the CJEU saw no problem with the Benelux Court of Justice because it represents a "step in the proceedings" before the national courts of the Member States concerned, it found no such links between intra-EU BITs and the judiciary of the relevant Member States. The Benelux Court though, can refer cases involving interpretation of EU law to the CJEU for preliminary ruling. Based on the foregoing, the CJEU concluded that an arbitral tribunal like the one established pursuant to Article 8 of the Dutch-Slovak BIT was not a court of tribunal

5 See CJEU, Case C-394/11, Valeri Hariev Belov v CHEZ Elektro Balgaria AD [2013], ECLI:EU:C:2013:48, paras. 39 and ff. See also CJEU, Case C-377/13, Ascendi Beiras Litoral e Alta, Auto Estradas das Beiras Litoral e Alta SAV Autoridade Tributária e Aduaneira [2014], ECLI:EU:C:2014:1754, para. 23. 
of a member state of the EU and, therefore, could not submit requests for preliminary rulings to the CJEU under Article 267 of the TFEU (paras. 46-49).

The second issue before the CJEU was whether the judiciary of the EU and its member states could exercise some form of control over the decisions rendered by the arbitral tribunal envisaged in the DutchSlovak BIT. The relevance of this matter is twofold: first, because an affirmative answer to this question would have meant that the "controlling" court could refer matters concerning the interpretation of EU law to the CJEU via requests for preliminary ruling; and second, because ironically, the Achmea decision originates in a request for a preliminary ruling by a tribunal of a member state.

In this respect, the CJEU noted that the decisions of the arbitral tribunal are final. It further noted that the arbitral tribunal can determine its own procedure and choose its seat and the applicable law to the proceedings. The CJEU acknowledged that in the instant case the arbitral tribunal chose Frankfurt as its seat and, as a result, that the German rules on the judicial review of arbitral awards applied to that case and this made it possible for the Government of the Slovak Republic to bring a case against the decision. However, the BIT did not guarantee the judicial review of the awards by ordinary courts. Therefore, the CJEU concluded that, in absence of review of the arbitral awards from domestic courts, the arbitral tribunal envisaged in the Dutch-Slovak BIT is not consistent with the EU treaties (para. 57).

The CJEU concluded its decision with a caveat, and affirmed that, in principle, an international agreement establishing a court tasked with the application and interpretation of the rules set forth therein is not in principle incompatible with EU law, provided that it respects the autonomy of the EU legal order. The case law cited by the CJEU to support this finding consists of decisions where the CJEU blocked the accession of the EU to international agreements because of the dispute settlement mechanisms laid down therein (Opinion 1/91 on the EEA Agreement, Opinion 1/09 on the Unitary Patent Court, and Opinion 2/13 on the accession of the EU to the European Convention on Human Rights (ECHR)) (paras. 57 and 58).

\subsection{Pre-Achmea}

The decision in Achmea, despite its far-reaching effects (it is probably the single decision of a tribunal wiping out the highest number of international agreements), was not surprising. Achmea echoes the case law of the CJEU (and its predecessors) where the establishment of international dispute settlement mechanisms was seen as undermining the autonomy of the EU legal order.

The origins of this conservative approach can be traced back to Opinion 1/91, where the CJEU found that the judicial supervision system established in the European Economic Agreement (EEA) between the EU and European Free Trade Agreement (EFTA) countries was inconsistent with the then EEC (European Economic Community) Treaty. It might be relevant to briefly sketch some of the features of the project for an EEA Court. The court established through this agreement was supposed to supervise the application of an agreement, the EEA, the aim of which is to expand the EU acquis to the EFTA countries. As a result, the wording of the EEA is identical to that of the EEC Treaty. The court was supposed to be composed of 8 judges, five of which being CJEU's judges. It was supposed to interpret the provisions of the treaties consistent with the rulings of the CJEU rendered before the entry into force of the EEA.

Still, the presence of a majority of CJEU judges, and the obligation to construe law in light of CJEU case law notwithstanding, the CJEU did not shy away from expressing its reservations. It held that the agreement did not specify whether it referred to the CJEU case-law as a whole, including the jurisprudence recognizing direct effect and primacy of EU law (para. 27). Furthermore, it expressed its skepticism regarding the mechanism for preliminary rulings embedded in the agreement. True, the EEA provided for a mechanism whereby the EEA Court and domestic courts in EFTA countries could refer interpretative questions to the CJEU. This tool was, nevertheless, conceived as a possibility and not as an obligation (for courts of last instance) and, in any event, there was no guarantee that the opinions of 
the CJEU would be considered as binding (paras. 56-59). These "contradictions" were considered to "undermine" the autonomy of the EU legal order. As a result, the CJEU found the dispute settlement mechanism embedded in the EEA was incompatible with the EEC Treaty.

The CJEU had the opportunity to define more clearly the boundaries of the notion of "autonomy" of the EU legal order, when it rendered its Opinion 2/13 on the EU's accession to the ECHR. There, the CJEU affirmed that dispute settlement mechanisms in international agreements to which the EU is a party are, in principle, not inconsistent with EU law (para. 182). This finding notwithstanding, the Opinion contained a strong proviso that undermined its practical importance. The CJEU in fact affirmed that the decisions of the institutions of the ECHR, including those of the European Court of Human Rights (ECtHR), should not bind the EU and its institutions to follow a particular interpretation of the rules of EU law (para. 184). The key to the respect of the autonomy of the EU legal order, therefore, seemed to be leaving the last word on the interpretation of EU law to the CJEU.

\subsection{What Changes with Achmea?}

On its face, Achmea reaffirms what had already been decided in Opinion 2/13. It is no coincidence that, in less than ten pages, Achmea cites Opnion 2/13 seven times. That is no surprise, in light of the fact that the same judge was the Rapporteur in both cases.

Nevertheless, reading between the lines of the judgement, Achmea seems to go even further than Opinion 2/13. The CJEU, in fact, did not just reaffirm its monopoly on the interpretation of EU law as an essential condition for the preservation of the autonomy of the EU legal order. The CJEU made important conclusions with respect to the automatic execution of international judgments as well. When judicial review of international awards (potentially, although not necessarily applying EU law) by domestic courts is not possible, then the international tribunals issuing similar awards will not pass the test of consistency with EU law as now established by the CJEU.

\subsection{Where are We Now?}

The full story regarding the destiny of international courts and tribunals under EU law is still to be written. Following Achmea, Opinion 1/17 discussing the consistency of ISDS chapters included in agreements establishing free-trade areas between the EU and third countries is now awaited with much anxiety. The outlook does not look promising for those espousing the "internationalist" view. In the post Achmea world, three questions are relevant for the survival of an international court or tribunal established by means of an agreement between the EU and third countries or among member states of the EU.

\subsubsection{Does the international court or tribunal apply EU law?}

The case law of the CJEU is particularly strict in this regard. In fact, an international tribunal has been considered to be applying EU law when EU law is reproduced in the context of an international agreement (See Opinion 1/91), or when EU law may be (but not necessarily is) used in the determinations made by the international adjudicators (Achmea). International courts and tribunals are called to evaluate whether states (or individuals when that possibility is provided for) have violated certain provisions of an international agreement. Domestic law is not part of the applicable law of international agreements. That should be sufficient, in principle, to shelter international courts from the CJEU's reject. However, evaluations based on domestic law are often necessary to better understand the terms of a dispute. Would a factual evaluation requiring the interpretation of provisions of EU law be allowed? The European Commission seems to be aware of the problems that the conservative attitude of the CJEU may cause. In this respect, it has introduced language in the text of the investment disputes chapter of CETA according to which the domestic law of the parties can only be considered by the 
Investment Tribunal "as a matter of fact". Is this clarification sufficient to address the CJEU's concerns? This point will be discussed infra.

\subsubsection{Can the international judge applying EU law submit a request for a preliminary ruling to the} CJEU?

This is a rhetorical question. The case law of the CJEU has reserved the possibility to submit requests for preliminary rulings to courts and tribunals of a Member State which meet certain conditions. Such conditions are explained in detail elsewhere (Wahl and Prete, 2018). A closer look at what kinds of courts and tribunals have been deemed to be (or not to be) "of a Member State" constitutes useful background to evaluate the reach of Achmea. In Dior, the Court found that the Benelux Court met the relevant requirements. The Complaints Board of the European Schools had a less lucky destiny. The Court in Miles concluded that the Board was established within an international organization which, despite the existence of certain links, was distinct from the EU and its Member States. Interestingly, the Board is required to apply general principles of EU law in the settlement of the disputes. Thus, on the one hand the Court requires all judicial bodies even theoretically applying EU law to respect its authority and to diligently submit preliminary ruling requests in case of doubt, and yet it rejects such requests when they come from bodies that are physically based in the EU and do apply EU law in the settlement of disputes. At the very least, the case law is not linear. Or, to borrow from Wahl and Prete (2018), we can even say that the Court reached a "paradoxical" result. What will happen if an international tribunal does decide to submit a request for a preliminary ruling? Chances are that the CJEU might reject such request since it does not come from a court or tribunal of a Member State.

2.4.3 When the international tribunal applying EU law cannot submit preliminary ruling requests to the CJEU, are its judgments automatically executed? Are they subject to the scrutiny of a domestic court in the EU?

The Court in Achmea noted that the arbitral tribunal determined its own procedure under UNCITRAL rules and chose its seat in Germany. It is only because German law so permitted that the Slovak Republic could obtain the judicial review of an arbitration award that would have otherwise been executed and that a domestic court filed a preliminary ruling request to the CJEU. The CJEU does not explicitly affirm so, but judicial review of arbitration awards could have saved intra-EU BITs. The problem with this solution, however, is that it is not realistic. Why would two states negotiate an agreement including an arbitration clause which would allow avoiding the recourse to domestic judges, if the awards would be subject to the scrutiny of the very same domestic judges?

\section{Achmea and ... Uncertainty}

Achmea decided that two EU member states could not enter an ISDS arbitration to adjudicate disputes coming under a BIT they had entered into.

Recall that, as per Article 207 TFEU, it is the EU, following the advent of the Lisbon Treaty that has the right to conclude agreements on FDI, and not its member states anymore. The foregoing was further clarified by the CJEU in its Opinion 2/15 on the Free Trade Agreement between the EU and Singapore. Furthermore, since both parties to the BIT were EU member states, Article 351 TFEU is inapplicable. Indeed, as the European Commission stated in its Micula State Aid decision:

It is clear from the wording of Article 351 of the Treaty that it does not apply in the present case, since the BIT is a treaty concluded between two Member States of the Union, Sweden and Romania, and not a treaty 'between one or more Member States on the one hand, and one or more third 
countries on the other'. Accordingly, the application of State aid law in the present case does not affect rights and obligation protected under Article 351 of the Treaty. ${ }^{6}$

Hence, viewed from this angle, Achmea should not be over-dramatized. All the CJEU suggested was that intra-EU BITs containing ISDS clauses of the type provided for in the Dutch-Slovak BIT are inconsistent with Article 344 TFEU. The decision seems to have already had its intended impact as, for instance, Poland announced its intention to unilaterally terminate its BIT with Portugal. ${ }^{7}$ Recall that the consistency of EU and third countries has yet to be decided, since Opinion $1 / 17$ is still pending.

And yet, the problem is not the ruling as such. It is the ruling in its context that poses a threat. We explain. ${ }^{8}$

\subsection{Does it Matter if it is Member States or the EU that Has Contracted?}

In Achmea, it is of course two member states that were involved in the dispute before the CJEU. The Achmea court though, cites Opinion $2 / 13$ in support of its ratio decidendi. In that case, it was the accession of the EU as such to the ECHR, and the ensuing acceptance of the rulings of the European Court of Human Rights (ECtHR) that was at issue. The EU member states were not involved.

And yet, the CJEU in that case as well found that submission to a different court would contravene the EU treaties. It is not, the CJEU maintains, submission to all international courts that would contravene the EU treaties. It does not identify "acceptable" and "unacceptable" courts either. Of course, that much would be too much to ask, since, even if it did, we would still be in the dark about courts to be established in the future.

What matters thus, is to understand the criteria that will tilt the balance to one or the right direction. Alas, this is where the CJEU planted a quicksand.

\subsection{Autonomy of EU Law ... Quicksand}

In para. 183 of its Opinion 2/13, the CJEU stated:

Nevertheless, the Court of Justice has also declared that an international agreement may affect its own powers only if the indispensable conditions for safeguarding the essential character of those powers are satisfied and, consequently, there is no adverse effect on the autonomy of the EU legal order

In para. 56 of Achmea, the CJEU held:

... a mechanism ... which could prevent those disputes from being resolved in a manner that ensures the full effectiveness of EU law, even though they might concern the interpretation or application of that law (emphasis added)

The terms used leave ample discretion to the CJEU, and quite frankly, it is impossible to predict ex ante how it will be exercised in future practice. What is the "essential character" of the EU legal order? What is its "full effectiveness"?

Take, for the sake of the argument, a dispute before the WTO (World Trade Organization), where a WTO panel is called to interpret the term "ordinary course of trade" appearing in the WTO Antidumping

6 Commission Decision (EU) 2015/1470 of 30 March 2015 on State aid SA.38517 (2014/C) (ex 2014/NN) implemented by Romania [Arbitral award Micula v Romania of 11 December 2013 (notified under document C(2015) 2112)] (OJ 2015 L 232, p. 43).

7 See Marcin Orecki, 'Let the Show Begin: Poland Has Commenced the Process of BITs' Termination' (2017) available at http://arbitrationblog.kluwerarbitration.com/2017/08/08/let-show-begin-poland-commenced-process-bits-termination/.

8 Rosas and Amati provide a very succint discussion of the pre-Achmea jurisprudence. See Allan Rosas and Lorna Amati, EU constitutional law, an introduction (Hart Publishing 2012). 
Agreement. The panel will do just that. Has it prejudged the full effectiveness of the EU legal order simply because the same term appears in the EU regulation on antidumping?

A formalist would say that, even if the same term appears in both texts, the WTO panel has interpreted the WTO Antidumping Agreement, and not the EU Antidumping regulation. Are we sure that the CJEU will accept this view?

Of course, the WTO is not much of an issue, since, although the CJEU has so far at least not equated it with an ISDS, it has progressively reduced its relevance. With the exception of antidumping, and a few Agreement on Trade Related Aspects of Intellectual Property Rights (TRIPs)-related provisions ${ }^{9}$, the CJEU has repeatedly stated that the WTO is no legal benchmark to judge consistency of EU law with its obligations assumed at the international level.

The question however, remains the same with respect to any other jurisdiction: under the circumstances described above, is a provision providing for submission of disputes to an international court to be denied consistency with Article 344 of the TFEU? The honest answer is we do not know. And yet, the CJEU in various judgments has been confirming that submission to international courts is not out of cards altogether. Internationalists are placated. Are they also safe in the knowledge when this is the case?

\subsection{But Surely There are Courts We Recognize}

The reader of Opinions 1/91, 1/09, 2/13, and now Achmea, will consistently find references to the, in principle, compatibility of provisions in international treaties to which the European Union is a member whereby submission of disputes to an outside court is forecasted. In Opinion 1/94, submission to WTO panels and the Appellate Body did not manage to attract a detailed discussion, because the question was not asked. It did in the opinions mentioned here. Which courts enjoy this privilege? For which reasons and under what conditions? We simply do not know as it all depends on the way the CJEU will implement the two paragraphs we have quoted in the previous Section.

The ECtHR failed the test. So did an intra-EU ISDS. Who is next? Most likely, the ISDS mechanism established through CETA.

As already anticipated, the European Commission is aware of the conservative attitude of the CJEU. For this reason, it is carefully attempting to avoid the rejection of international agreements that it has concluded with third countries after lengthy negotiations. The EU and Canada agreed on the establishment of a court system tasked with the resolution of investor-state disputes arising under the CETA. Article 8.31 of CETA stipulates that the tribunal, when determining the consistency of a measure with the CETA, may consider domestic law only "as a matter of fact". This clarification, which echoes old-fashioned public international law doctrines (Certain German Interests in Polish Upper Silesia), may not be a sufficient guarantee for the CJEU. Although considered as "fact", EU law might still be used and interpreted by an international tribunal placed outside the EU judicial system and with no possibility to file preliminary rulings requests to the judges in Luxembourg. In light of the case law of

9 The CJEU has repeatedly confirmed that WTO law cannot serve as a benchmark for the consistency of EU law before EU courts. Over the years, it has famously established two exceptions in Nakajima and Fediol. According to this case law, the CJEU can evaluate the inconsistency of an act of EU law with the obligations assumed by the EU under the GATT/WTO regime when that particular act makes exlicit reference to a provision of WTO law or when it is clear that the EU institutions adopted a specific act with the intention to implement WTO law. In 2015, the CJEU further narrowed the scope of those two exceptions in Rusal Armenal. In this last case, the Court basically conflated the two exceptions. It found in fact that reference in the preamble of the EU Basic Anti-Dumping Regulation to the will of the EU institutions to implement the Anti-Dumping Agreement is not enough, and that in order to use WTO law as a benchmark for the legality of a provision of the Basic Anti-Dumping Regulation, it is instead "necessary to be able to deduce from the specific provision of EU law contested that it seeks to implement into EU law a particular obligation stemming from the WTO agreements" (See CJEU, Case C-21/14, European Commission v. Rusal Armenal ZAO, [2015], ECLI:EU:C:2015:494, para. 46). 
the CJEU, this looks problematic. In any event, the CJEU will soon clarify this point when rendering its Opnion 1/17 on the compatibility of CETA with EU law.

\subsection{And for the Rest?}

Take any contract between private parties, which is subject to binding arbitration, not subject to domestic courts' review. If the applicability of EU law is an issue, the losing party will be relying on Achmea to see its liability reduced to ashes. One might wonder of course, why the effectiveness of EU law has been eviscerated simply because an arbitrator living in Arbitrator-land has issued a decision, which does not have to bind the CJEU in a dispute between two private parties.

\subsection{Is There a Safe Way?}

The only safe way, it seems, is to have referral to the CJEU. CJEU would have no objection at all to the establishment of any court/arbitral tribunal to discuss any issue under the sun, as long as some sort of mechanism mimicking preliminary rulings by national courts of member states were to be introduced in the relevant agreement. This seems quite a straightforward way to overcome Achmea. The problem though, is why would international partners privilege submission of their disputes with the EU and its member states to the court in Luxembourg? After all, it is a European court, and it is quite hard to sell it as the "impartial" arbiter to adjudicate disputes between its member states and the EU institutions, and third parties. Since the risk of any agreement to influence the effectiveness of EU law cannot outright be excluded (except for cases where member states have not transferred competence to the EU, a progressively shrinking domain), the CJEU will have to be omnipresent, otherwise there is a risk that it might be opposing deals concluded by the EU and its member states.

Opinion 1/17 is becoming quite a landmark case even before it has been issued. The CJEU will rarely have more of an opportunity to prove that the analysis above, and similar analyses by other authors, ${ }^{10}$ is an exaggeration. The judges have another opportunity to disaggregate the general principles that they have used in prior case law into functional, workable criteria that will allow stakeholders to plan ahead in the safe knowledge that their actions will not be overturned by virtue of unfathomable benchmarks.

\section{Concluding Remarks}

Achmea concluded that BITs signed between EU Member States including ISDS arbitration clauses the decisions of which are not reviewable by ordinary courts are incompatible with EU law. This seems like a narrow judgment. It could be though that the rationale of the decision has far-reaching implications. It might substantially limit the power of EU institutions to conclude international agreements containing dispute resolution mechanisms. While we are waiting for the CJEU to state some (probably) definitive words in Opinion 1/17, we cannot be certain of anything anymore.

Several scholars and practitioners have referred to the CJEU as "the gatekeepers" of the autonomy of EU law, both externally (Snyder, 2003), as well as internally (Wahl and Prete, 2018). This view seems more and more reasonable in light of recent developments discussed in this note. The CJEU does not seem to find a way to reconcile with the idea that it might co-exist with other international adjudicating systems. True, the distinction between international responsibility and (lack of) domestic implementation offers guarantees to the EU's partners that they will at the very least be compensated. Some though might not be satisfied with liability rules.

10 Marco Bronckers, 'The relationship of the EC courts with other international tribunals, Noncommittal, respectful or submissive?' (2007) 3 Common Market Law Review 44, 601-627; Tobias Lock, 'The ECJ: what are the limits of its exclusive jurisdiction?' (2009) 3 Maastricht Journal of European and Comparative Law 16, 291-314. 
Worse, the implications of this attitude risk to be systemic, as the European Commission finds itself between a rock and a hard place in international negotiations. On the one hand, it has to win the resistance of certain counterparties in the attempt to include binding and independent adjudicating systems in international agreements. On the other hand, even when it manages to persuade its interlocutors, it cannot be sure that the CJEU will accept the results of the negotiations. It will have to navigate unchartered waters, until the CJEU has clarified the score.

In our view, the most promising avenue for the CJEU is to abandon the current course, and opt for a new route. Employing a formal criterion to distinguish between legal orders, will allow it to open to international adjudication, a key feature in today's world characterized by proliferation of international contracts. In this sense, a provision in a free-trade area, even if identical to EU law, belongs to a distinct order, and its interpretation can never undermine the autonomy of EU law.

The CJEU would thus keep its role of gatekeeper to decide which part of foreign law would find its way within the four corners of Luxembourg orthodoxy. This could be done ex ante through advisory opinions, and ex post through the Court's case law, as per current practice. The EU is experiencing increasingly difficulties in exercising its bargaining power at the world level. The Achmea decision is an intensifying factor. The CJEU has shown many times that it can rethink its past case law and (implicitly) change lanes. A change of lane is highly recommendable here.

\section{Reference List}

Marco Bronckers, 'The relationship of the EC courts with other international tribunals, Noncommittal, respectful or submissive?' (2007) 3 Common Market Law Review 44, 601-627.

Tobias Lock, 'The ECJ: what are the limits of its exclusive jurisdiction?' (2009) 3 Maastricht Journal of European and Comparative Law 16, 291-314.

Marcin Orecki, 'Let the Show Begin: Poland Has Commenced the Process of BITs' Termination' (2017) available at http://arbitrationblog.kluwerarbitration.com/2017/08/08/let-show-begin-polandcommenced-process-bits-termination/.

Allan Rosas and Lorna Amati, EU constitutional law, an introduction (Hart Publishing 2012).

Francis Snyder, 'The Gatekeepers: The European Courts and WTO Law' (2003) 2 Common Market Law Review 40, 313 - 367.

Nils Wahl and Luca Prete, 'The Gatekeepers of Article 267 TFEU: On Jurisdiction and Admissibility of References for Preliminary Rulings' (2018) 2 Common Market Law Review 55, 511-548. 


\section{Author contacts:}

\section{Carlo M. Cantore}

World Trade Organization

Dispute Settlement Lawyer, Rules Division

Rue de Lausanne 154

1211 Geneva (Switzerland)

Email: cantore.carlo@gmail.com

\section{Petros C. Mavroidis}

Columbia Law School and University of Neuchâtel

Edwin B. Parker Professor of Law at Columbia Law School

Jerome Greene Hall, Room 734

435 West 116th Street

New York, NY 10027

Email: pmavro@law.columbia.edu

Email: Petros.Mavroidis@unine.ch 